\title{
Vessel Patency Indicator
}

National Cancer Institute

\section{Source}

National Cancer Institute. Vessel Patency Indicator. NCI Thesaurus. Code C119558.

An indication as to whether an artery is patent (free of TLR or restenosis) following intervention. 